\title{
PHYSICAL EDUCATION FOR STUDENTS WITH SPECIAL EDUCATION NEEDS IN EUROPE: FINDINGS OF THE EUSAPA PROJECT Aija Klavina*, Martin Kudláček ${ }^{* *}$
}

\author{
* Latvian Academy of Sport Education, Latvia \\ ** University of Palacky in Olomouc, Czech republic
}

Adapted Physical Activity (APA) is a service delivery profession and an academic field of study This study describes outcomes of the European Standards in Adapted Physical Activity project in adapted physical education area. The differences in special education services, including Adapted Physical Education in the 10 project partner countries were identified. The academic standards in APE were defined in four parts: (1) professional competencies of physical education teachers; (2) occupation description of the of physical education teachers, (3) Functional Map in APE; and (4) Knowledge, Competence and Skills Framework in APE. Outcomes of the project with identified further recommendations for EU Commission were provided in order to promote implementation of inclusive education strategies for students with special education needs in physical education.

KEYWORDS: adapted physical education, special education needs

\section{INTRODUCTION}

The European Union (EU) is an international organization which links 27 countries and operates with wide power to formulate, shape and implement community policy. Since, any political system is obligated to respond to the needs of its people, EU is no exception. The European Commission (EC) stands at centre stage and has the responsibility to take the decisions necessary for the attainment of the goals also has the right of establishment and defining common policies. In confirmation to EC'S commitment to education, EC responded early to the outcome of the first European summit in 1972, where the heads of the governments agreed that education is the most important vehicle that could lead Europe to a new era (O’ Hanlon, 1993).

Inclusive education is based on the right of all learners to a quality education that meets basic learning needs and enriches lives. Focusing particularly on vulnerable and marginalized groups, it seeks to develop the full potential of every individual. The ultimate goal of inclusive quality education is to end all forms of discrimination and foster social cohesion (UNESCO). Inclusion is a concept that has been widely spread across Europe, however some countries do not use similar terms (i.e integration). The idea of inclusion motivated a lot of European countries to approve concrete legislative initiatives aimed at considering the student with SEN not as a guest in school but as a full participant and member. However, the situation regarding inclusion varies across Europe. For example, the proportion of school age children having special educational needs differs widely, from about $1 \%$ in Greece to over 10\% in Estonia, Denmark, Finland and Iceland. Definitions and categories of special education needs and disabilities also vary across EU countries. Some countries define only one or two types of special needs. Others categorize students with SEN into more than ten categories. Most countries distinguish 6 to 10 types of special needs. The proportion of school-age pupils in segregated educational settings ranges from under $0.5 \%$ in Greece, Italy, Portugal, and Spain to 6\% in Switzerland (Special Educational Needs in Europe, 2005).

Physical education (PE) and sports play an important role in European society and its specific nature were recognized in December 2000 in the European Council's Declaration 
(Nice Declaration, 2000). Physical education and sport is considered as a growing social phenomenon which makes an important contribution to the EU's strategic objectives of solidarity. However, PE and sport is also confronted with new threats and challenges which have emerged in European society, such as racism towards marginalized groups as individuals with disabilities are considered. In order to give strategic orientation on the role of PE and sport in Europe, to enhance the visibility of $\mathrm{PE}$ and sport in EU policymaking and to raise public awareness EC published the document "White Paper in Sport". This initiative aims among other things to encourage social cohesion in more integrated societies. Thus, all European residents should have access to $\mathrm{PE}$ and sport especially people with disabilities. However, many governments have committed themselves through legislation to making provision for PE but they have been/ or are being slow in translating this into action (Hardman, 2008).

Physical education is one of the most important disciplines within the school curriculum where inclusion takes place first (Sherrill, 2004). In most European countries teachers are not permitted to decide if they will have a student with a disability in their class, but they can decide to which extent they will include this student (Lienert et al., 2001). Unfortunately, there are not extensive reviews of studies on the benefits of inclusive physical education (Block and Obrusníková, 2007 , O’Brien, Kudláček \& Howe, 2009). If a student is unable to participate safely or successfully in regular $\mathrm{PE}$, then he/ or she should receive Adapted Physical Education. Adapted Physical Education is developmentally appropriate $\mathrm{PE}$ at its finest. It is adapting, modifying, and /or changing a physical activity so it is an appropriate for a person with disability.

Although, Europe's strong commitment to inclusive education and the significant changes that have occur through these years, still each country remains unique in its approach to education of students with SEN in schools. Taking large variety of education systems into account, it is not surprising that different forms of structures and practices are evident across Europe regarding inclusion of students with SEN in general physical education.

The aim of the following chapter is to explore the EC's policy on education of students with SEN in the countries which are represented in the European Standards in Adapted Physical Activity (EUSAPA) project. However, the diversity of education systems, legislations, terminology, teacher training programs in Europe rise the need for caution when comparing situation from country to country. Next, the short overview on legislation in ten EU countries involved in EUSAPA Project will be presented.

In Belgian legislation special education is reserved for children and adolescents, on the basis of a multidisciplinary assessment. Specialized education is provided for students whose needs are of the same type, their needs defined in terms of the principal disability common to one of eight disability groups. Adapted Physical Education (APE) is not explicitly mentioned in legislation and the professional preparation in relation to APE is being delivered mainly at the Catholic University in Leuven.

In Finland students are considered as SEN when their possibilities for growth, development or learning are decreased by the reason of disability, sickness or decreased working order. Students in need of psychological or social support or who are at risk in these areas have the right to have assistance for their learning. Students with minor learning or adjustment difficulties have the right to receive part-time special needs education in conjunction with mainstream instruction. All students have the possibility either for inclusive or special education services regarding the severity. Adapted physical education can be delivered by teachers such as daycare, classroom, special education, basic education, P.E. teachers and APE-teachers. Teacher preparation in relation to APE is being delivered in higher level institutions such as the University of Jyväskylä. 
Furthermore, in France there is no established term which refers to the population of children who benefit from specific measures defined on the basis of special educational needs: the terms used (disabled children, nonadapted children) are all very specific, linked to certain connotations, and marked by a historical situation. According to the Law $\mathrm{n}^{\circ}$ 2005-102 of February 11, 2005 for equal rights and opportunities, participation and citizenship of persons with disabilities, the definition of disability is constituted by any limit on activity or restriction on the participation in social life in person's environment due to a substantial, durable, or permanent alteration of one or several physical, sensorial, mental, cognitive, or psychic functions, to a multiple disability or to a disabling health problem. APA professionals in France are explicitly mentioned as a profession in the law. Article L.212-1 of Sport Code, Decree of 12/10/2006 published (official Journal JO: $\mathrm{n}^{\circ} 259 \mathrm{du}$ 08/11/2006 text number 21) by the Ministry of Health, Youth, Sports and Associative Life states: A professional with a Bachelor degree in APE can lead physical activity sessions in the areas of health, rehabilitation or integration for persons with motor or psychological disabilities but not in the area of coaching. Adapted Physical Education studies are offered in French institutions of higher education.

In Ireland SEN is defined in relation to a person's restriction in the physical, sensory, mental health, learning disability capacity to participate in and benefit from education. Although APA is not explicitly mentioned in the special education laws, however, the Special Needs Education Act 2004 (EPSEN) defines Support Services for inclusion, which also includes inclusive PE. Relevant services can be: (a) Junior Cycle PE ProgramInclusion Officer, (b) Physical Education Association of Ireland, (c) Primary Curriculum Support Programme or (d) Special Education Support Services. Adapted Physical Education studies or modules are delivered in higher education institutions such as the Tralee Institute of Technology .
In Portugal students with SEN are defined as children and young people receiving special education because they have difficulties in their learning process and participation in education, considering the interaction between inter-related factors and limitations in their functioning (DGIDC Direcção-Geral de Inovação e de Desenvolvimento Curricular (Innovation and Curricular Development Department), Ministry of Education). Adapted Physical Education is not explicitly mentioned in the law; however the law includes statements about areas where special needs have been identified and requires certain type of specialised support. Physical education is one of those areas. The professionals that work with children with SEN are PE teachers who completed their studies in institutions such as the University of Coimbra which in its curriculum APE are mandatory for all students.

In Latvia SEN is considered any child that has visual impairment, hearing impairment, learning disability, mental retardation, language problems, chronic diseases like diabetes, asthma, physical problems, and psycho neurological diseases (Regulation Nr.542, LMES, 2003). Adapted physical education is not explicitly mentioned in law. The requirements for pedagogical staff working at education settings, such as teachers, are a higher education study diploma in a specific subject i.e sport education. The APE teacher is not yet included in the list of professions that are mandatory to work in education and sport education. Adapted physical education is being taught as part of studies of $\mathrm{PE}$ and physiotherapy at the Latvian Academy of Sport Education in Riga. In Poland children and youth with SEN are considered those with developmental disabilities such as mental retardation, hearing impairments, visual impairments, physical disabilities, chronic diseases, psychiatric problems, multiple disabilities, autism, behavioral problems and language and communication problems (Act on School Education of 7 September 1991). All pupils with SEN receive the assistance from Psychological and Educational Services 
Centres free of charge and on the voluntary basis. Results of psychological, pedagogical and medical assessment serve as a basis for qualifying pupils for suitable forms of education either in general schools, integration schools/classes, or special schools/classes. Teachers in special PE should participate in special life-long learning courses for developing their own competencies (ACT about System of Education, 7/09/1991).

In Sweden the basic principle in education from childcare to transition period is "a school for all"- access to an equivalent education for all. The Swedish Education Act (1985:1100) stipulates that all children and young people must have access to equal quality of education, irrespective of gender, their geographical place of residence and their social and financial situations. While the disability is not highlighted in the Education Act, but in the curriculum it is emphasized that every school has a special responsibility for pupils with disabilities. The municipalities must provide children, adolescents and young adults with various disabilities with an education equal to that received by others in the community. There are also programs of Special Needs Education that train specialists to work as consultants to teachers. It is expected that from 2011-2012 year some training in Special Educational Needs will be compulsory for all new teachers (Jerlinder \& Danermark, 2007).

The Czech Act on Education provides for children with special educational needs and their right to education, whose "content, forms and methods suit their educational needs and abilities." Support measures that these children are entitled to are defined by Decree No. 73/2005 as follows: special methods, forms and procedures, special textbooks, teaching materials, compensation aids, rehabilitation aids, special education subjects in addition to regular subjects, services of an assistant teacher, reduced number of children in class, provision of pedagogical-psychological services and other potential adjustments under Inclusive Education Plan. In addition, the Czech
Republic is now implementing the National Action Plan for Inclusive Education, which deals with the issue in a much broader sense with the aim of preparing a comprehensive systematic strategy for making the Czech education system accessible to all children.

Legislation in the United Kingdom (UK) prohibits discrimination in education and supports inclusive education. The UK also has obligations under international human rights law to provide inclusive education for all children. On October, 2010, the Equality Act came into force stating that it is unlawful for any education provider, including a private or independent provider, to discriminate between pupils on grounds of disability, race, sex, gender reassignment, pregnancy and maternity, religion or belief, or sex.

\section{Competencies of Physical Education Teachers}

Physical education is a compulsory part of education in most European countries. What differs is the amount of allocated teaching hours for PE in EU countries, the approach to curriculum and the competencies of $\mathrm{PE}$ teachers. For example, during the last decade time allocated for PE has increased only in $16 \%$ of EU countries, remained the same in $68 \%$ of countries, and has been reduced in $16 \%$ of countries (Hardman, 2008).

Learning more about teachers concerns, perspectives and experiences with inclusive PE can help European policy makers with policy and decision-making related to school rules and curriculum guidelines. Teachers can also feel like their voice is being heard and finally this information can be used for teacher preparation programs. Currently, most teachers do not feel competent to teach students with SEN in inclusive PE classes and in most cases there is absence (or lack of) support services and resources to facilitate inclusion in PE. However, there are notable features concerning differential variations between different parts of Europe. For example, in central and Eastern Europe inclusion is less implemented than in the overall EU countries in average (32\% as opposed to 45\%). Also, facility provision for 
students with disabilities is a more acute problem in central and eastern Europe (60\% of countries report deficiencies, whereas only 25\% report deficiencies in Western Europe). Conversely, lack of staff expertise is perceived to be greater in Western Europe than in eastern European countries (Hardman, 2008). In a study that was conducted in the USA and Germany (Lienert et al., 2001) reported that PE teachers were worried about lack of resources, large class sizes and inadequate facilities. Teaching was also reported to be much more difficult in an inclusive setting. Finally, teachers held collaboration concerns about support and team teaching with other professionals or support personnel. Morley, Bailey, Tan and Cooke (2005) also found that teachers were concerned with the lack of support services and training and also about the accessibility of environment. Finally, Herold and Dandolo (2009) emphasised the need to upgrade initial teacher training programs to address inclusive PE more effectively.

Regarding the professional preparation Hardman (2008) and his colleagues recommended that consideration be given to recognising three category levels of $\mathrm{PE}$ teacher: (a) Physical Education Teacher (One
Subject Specialist) usually 240 ECTS dedicated to acquiring PE related competencies; (b) Physical Education Teacher (2-3 Subjects) usually minimum of $35-50 \%$ (that is 84-120 ECTS) of content excluding professional training is PE-related; and (c) Generalist Teacher usually minimum of $10 \%$ (that is 24 ECTS) of content is PE-related. The 'Generalist Teacher' will usually be responsible for teaching $\mathrm{PE}$ in primary schools. This way it can be achieved an appropriate training in pre-service and inservice PE teachers education related to inclusive PE, which should empower them to teach students with SEN in an inclusive setting.

The AEHESIS (Aligning a European Higher Education Structure in Sport Science, 2003) project aimed to align professional preparation and develop qualification framework in four sport science areas: 1) sport coaching, 2) physical education, 3) health and fitness, and 4) sport management. About 70 partners from 28 countries were involved in this three year project. The project outcomes regarding PE present generic and specific knowledge and skills needed by physical educators in Europe (Table 1).

Table 1 Generic and specific knowledge and skills needed by physical educators in Europe

\begin{tabular}{|c|c|c|}
\hline & Knowledge & Skills \\
\hline & $\begin{array}{l}\text { - Knowledge and understanding of pupils' individual needs } \\
\text { and development } \\
\text { - Knowledge of a curriculum that is } \\
\text { formatively/developmentally based and progressively } \\
\text { sequenced with clearly defined aims, learning outcomes } \\
\text { and key concepts } \\
\text { - Knowledge of a range of pedagogical and didactical } \\
\text { processes and skills to include evaluation of student } \\
\text { progress, reflective thinking, appropriate decision-making } \\
\text { and initiative taking, and adaptive behaviours } \\
\text { - Knowledge and skills to support pupil's learning, } \\
\text { progression and development within the school curriculum } \\
\text { in an informed and imaginative manner } \\
\text { - Knowledge of ethically and professionally sound attitudes, } \\
\text { values and safe behaviours (teaching and learning, } \\
\text { physically and socially) } \\
\text { - Knowledge of the school as a social institution and } \\
\text { contextualisation of professional practices } \\
\text { Management of risk-taking }\end{array}$ & $\begin{array}{l}\text { - Curriculum planning and delivery competence with a } \\
\text { range of teaching interventions } \\
\text { Effective classroom management with the ability to } \\
\text { respond to, and manage, change learners, and handle } \\
\text { issues in an informed way so as to develop their practice } \\
\text { in a changing world. } \\
\text { - } \text { Application of a range of pedagogical and didactical } \\
\text { processes and teaching/learning management } \\
\text { techniques/skills that guarantee differentiation of } \\
\text { learning tasks and teaching styles, which are appropriate } \\
\text { both to the tasks and to the students } \\
\text { - } \quad \text { Effective planning and setting of expectations } \\
\text { - } \text { formative progress and achievement } \\
\text { - Manage own performance and development } \\
\text { - Manage and develop staff and other adults } \\
\text { - Policy formulation and strategic leadership }\end{array}$ \\
\hline
\end{tabular}


- $\quad$ PE-related subject (specialist) knowledge and understanding to include acquisition of a subject content knowledge base in a variety of physical activities and related scientific areas of study embracing key concepts and skills that provide the material to be taught and the ability to employ a range of teaching styles and methods within a variety of contexts

- Knowledge of PE curriculum development and implementation

- Knowledge of structure, function and control of physical systems as well as understanding and application of anatomical and biomechanical principles to movement

- Knowledge of PE/Sport in society, historical, cultural and sociological developments

- Psychological/sociological knowledge of human movement

- Knowledge of preparation, conduct and reporting of a PErelated project

\section{Table 1 (continued)}

Furthermore, a more specific European project aiming in providing appropriate training for PE teachers to be successful in inclusive $\mathrm{PE}$ is the EIPET (European Inclusive Physical Education Training) (www.eipet.eu). The project aimed to tackle difficulties that arise associated with the inclusion of students with disabilities into mainstream education. The EIPET project's main aim was to offer a ready to roll module and associated resources for addressing effective inclusion of students with disabilities in mainstream education. The module user groups may include undergraduate $\mathrm{PE}$ teacher training, primary school PE teacher training and in-service PE teacher training.

Following the EIPET module (course) PE teachers learn to: (a) Plan developmentally appropriate learning experiences in PE, which are also suitable for students with SEN; (b) Teach students with SEN in an inclusive setting; (c) Evaluate progress of learning of students with SEN; and (d) Advocate for the needs and rights of students with SEN. The module consists of 48 contact hours (12 weeks $\mathrm{x} 4$ hours) with 24 hours of lectures aimed to cover the knowledge base identified on the knowledge, skills and competencies
- Actively commit to the provision of equal opportunities respecting principles of inclusion and differentiation of teaching in $\mathrm{PE}$

- Ability to demonstrate competence in PE curriculum planning and review and appreciate the need for curriculum development connecting theory with practice

- Apply a range of PE-related practical and teaching skills

- Ability to synthesise and apply knowledge and understanding to the critical analysis and evaluation of physical education theory research and practice

- Relate aims of PE to more general curricular objectives

- Prepare, conduct and report on a PE-related project framework, 12 hours of tutorial aimed to assist student in planning, discuss specific needs, encourage sharing of ideas, encourage reflective practice and 12 hours of practicum aimed to give students a positive experience, provide progression which will increase student confidence and provide contacts and experiences with local disability organizations. It is important to emphasize the need to have practicum as integral part of this module as only contact and positive experience in work with students with SEN can assure acquiring substantial competencies needed in inclusive PE. However, the AEHESIS an EIPET projects did not follow the guidelines of sport and active leisure sector qualification strategy developed by EOSE (2008). There are seven steps considered with the responsibility to develop work based competence frameworks and qualifications in sport sector, including physical education within the European Qualification Framework (EQF) and the European Credit and Vocational Education and Training System (ECVET) (Figure 1.).

The outcome of these two projects in combination with the EOSE guidelines was main professional source for developing EUSAPA structure and framework in adapted physical education. 
Figure 1.The sport and active leisure sector qualification strategy

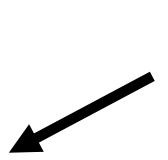

2- OCCUPATIONAL

MAP
1 - DEFINE SECTOR/ MAP

OF EMPLOYMENT
3- OCCUPATIONAL

DESRIPTION

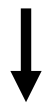

4 - FUNCTIONAL MAP
SPORT AND ACTIVE

LEISURE SUB-SECTORS

5- WORK BASED COMPETENCE FRAMEWORK

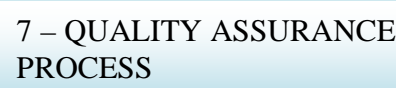

7 - QUALITY ASSURANCE PROCESS

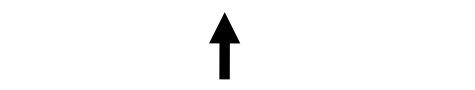

6 - KNOWLDEGE/ LEARNING OUTCOMES FRAMEWORK

\section{Adapted Physical Education Teacher/ Consultant Occupation Description}

Adapted physical education teachers are considered to be the main source of support to general physical education (GPE) teachers in the PE classes. Currently however, APE school based professionals either do not exist or are very limited across EU countries. The nature of work of APE teachers in Europe has not been studied. The only information available is from the USA where this profession has been well recognized since 1960s. Kelly and Gansender (1998) have pointed out that APE can provide both direct and indirect services, while direct services mean direct teaching of children with disabilities and indirect service means providing support to teachers attempting to include children with disabilities in their GPE. A study by Lytle and Collier (2002) investigated APE specialists' perceptions of consultation. Results indicated that the skills, attitudes and knowledge of the APE specialist combined with the educational environment were influential factors in the types of services provided. The use of consultations and their implementation were often influenced by the social, intellectual and physical environment. All participants commented that no formal training in consultation was provided as part of their training. In another study Lytle and Hutchinson (2004) discovered the following roles of the APE teachers in the USA: (a) advocator; (b) educator; (c) courier; (d) resource coordinator; and (e) supporter/helper. There were some negative reactions to the supporter/helper role, as the situation of territorial issues with the GPE teacher often arose. Overall it was highlighted that the various roles in the consultation process is a huge part of the APE teacher's daily life. Specific training in consultation was not part of the participants' APE training. Lytle and Hutchinson suggested that more training in areas such as adult interactions and effective communication in the consultation process is required. Kudláček et. al. (2008) studied the nature of work and roles of public school adapted physical educators in selected school districts in the United States with the aim of adding to the information base to enable the improvement of service delivery and professional preparation. Results showed the differences in the nature of work among APE specialists. Participants had high teaching loads (44-90 students) and served a wide range of schools (1-20), which created quite different teaching profiles. Most teachers were involved in APE consulting. Results also indicated the need to incorporate issues of consulting into teacher preparation and to change the university studies to make them 
more relevant to "real life teaching". It is important to mention that in the USA there are national standards APENS (Adapted Physical Education National Standards) and APE professionals passing the exams can become Certified APE specialists (CAPEs).

The EUSAPA project executive team developed interview guides to explore the situation regarding APE specialists in all project member countries. The interview guides included 14 questions on nature of job, professional responsibilities, advocacy, adaptations, and collaboration with other specialists. Because of time and financial constraints, data obtained from PE countries were collected in a frame of selected case studies and were not cross-national representative. The interview results revealed that the APE is not mandated in national legislations or regulations considering inclusive or special education. However, the data provided illustrative examples and indicated trends and tendencies to be used in formulating the functional map and knowledge, competence and skills framework for APE professionals. For example, in France the professional with a Bachelor degree in APA can lead physical activity sessions (not sport training sessions) aiming health maintenance, rehabilitation or integration for persons with motor or intellectual disabilities. In other countries such as Portugal, Poland, Latvia PE teachers working with students with SEN are required to attend in-service training on APA, or these teachers are with complementary formation on APA (at undergraduate or post-graduate level). While students with disabilities are included in general education with growing frequency across Europe, all partners indicated that there is lack of guidelines on functions, knowledge and skills of APE professionals working with school age students with SEN.

\section{Functional Map in Adapted Physical Education}

Functional Map (Table 2) describes all the functions or activities that may be performed by APE professional working in education, training and human resource management, either directly or indirectly (as service, or resource/ consultation provider). These EUSAPA aims are reflecting the best practice at a European level. The functional map both reflects current practice and anticipates the functions which may become more predominant in future when there will be need for APE specialists across Europe because of increased inclusions of students with disabilities in general education. Not all these functions will necessarily be performed in each school in every country. An individual school or teacher may select and perform a number of these functions according to their needs and possibilities. The Functional Map is used as the basis for drafting standards for these functions. The resulting standards will describe what someone applying APE/APA needs in terms of the competence, knowledge and skills. The European Standards in APE can then be used to design appropriate APE staff development programs and assess whether staff perform these functions effectively.

Table 2. Functional Map in Adapted Physical Education

\begin{tabular}{|l|l|l|}
\hline \multicolumn{1}{|c|}{ Key Area } & \multicolumn{1}{|c|}{ Key Roles } & \multicolumn{1}{c|}{ Key Functions } \\
\hline $\begin{array}{l}\text { A. Plan developmentally } \\
\text { appropriate learning experiences } \\
\text { in physical education (PE), } \\
\begin{array}{l}\text { which are also suitable for } \\
\text { students with special educational } \\
\text { needs (SEN) }\end{array}\end{array}$ & $\begin{array}{l}\text { A.1. Assess the needs (current level } \\
\text { of performance) of students with } \\
\text { (SEN). }\end{array}$ & $\begin{array}{l}\text { A.1.1 } \\
\text { Identify the special needs of students in } \\
\text { relation to adapted physical education (APE) } \\
\text { (e.g. information from family, using } \\
\text { appropriate screening tests). } \\
\text { Identify the support services and resources, } \\
\text { which can facilitate APE (e.g., assistant } \\
\text { personnel, equipment, environment) } \\
\text { Identify special needs for the purposes of } \\
\text { prescription of individual goals and the most } \\
\text { appropriate teaching strategies. }\end{array}$ \\
\hline
\end{tabular}




\begin{tabular}{|c|c|c|}
\hline & & $\begin{array}{l}\text { A.1.4 Identify competencies and attitudes of } \\
\text { students, teachers and other staff in relation to } \\
\text { participation of students with SEN in physical } \\
\text { education. }\end{array}$ \\
\hline & $\begin{array}{l}\text { A.2. Adapt school curriculum in } \\
\text { physical education to meet the } \\
\text { individual needs of all students with } \\
\text { special educational needs. }\end{array}$ & $\begin{array}{l}\text { A.2.1. Identify the strengths and weaknesses in } \\
\text { school physical education curriculum in } \\
\text { relation to adapted physical education. }\end{array}$ \\
\hline & $\begin{array}{l}\text { A3. Plan developmentally } \\
\text { appropriate learning experiences in } \\
\text { adapted physical education. }\end{array}$ & 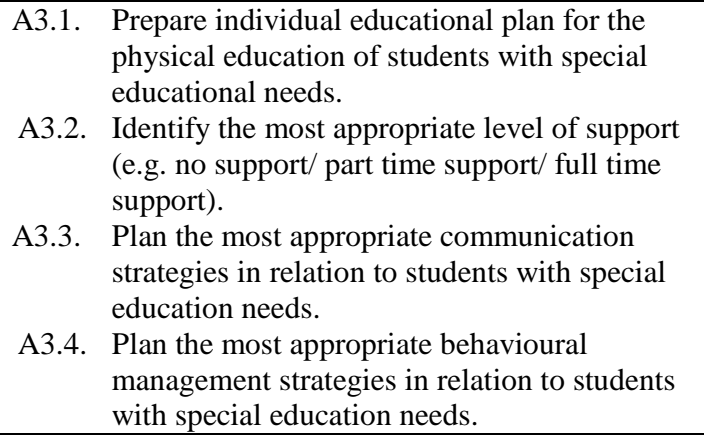 \\
\hline & $\begin{array}{l}\text { A4: Prepare teaching environment } \\
\text { before arrival of student with special } \\
\text { educational needs. }\end{array}$ & $\begin{array}{ll}\text { A4.1. } & \text { Prepare assistant personnel (e.g., teacher } \\
& \text { assistants, peer tutors) } \\
\text { A4.2. } & \text { Prepare other students } \\
\text { A4.3. } & \text { Prepare school staff } \\
\text { A.4.4. } & \text { Ensure that facilities, equipment and } \\
& \text { environment are appropriate and safe. } \\
\end{array}$ \\
\hline & $\begin{array}{l}\text { A.5. Collaborate with out of school } \\
\text { organisations. }\end{array}$ & $\begin{array}{l}\text { A.5.1. Contact relevant community based disability } \\
\text { organisations for potential cooperation (e.g. } \\
\text { Special Olympics, Local sports clubs). }\end{array}$ \\
\hline \multirow[t]{3}{*}{$\begin{array}{l}\text { B. Teach students with special } \\
\text { educational needs together with } \\
\text { students without SEN }\end{array}$} & $\begin{array}{l}\text { B1. Adapt teaching in order to meet } \\
\text { the needs of ALL students in adapted } \\
\text { physical education. }\end{array}$ & $\begin{array}{l}\text { B1.1. Use appropriate adapted equipment, which can } \\
\text { facilitate inclusive physical education (e.g. } \\
\text { brightly coloured, sounded, lighter or heavier, } \\
\text { bigger). } \\
\text { B1.2. Use task analysis for desirable skills. } \\
\text { B1.3. Adapt the rules of games, teaching style and } \\
\text { physical setting (current environment) to } \\
\text { facilitate participation. } \\
\text { B1.4. Use appropriate instructional accommodations } \\
\text { (e.g., physical/verbal cues, prompts, feedback, } \\
\text { reinforcement). }\end{array}$ \\
\hline & $\begin{array}{l}\text { B2. Manage students' behaviour to } \\
\text { assure the most appropriate and safe } \\
\text { learning for ALL students in APE. }\end{array}$ & $\begin{array}{l}\text { B2.1. Positive/negative reinforcement of } \\
\text { desirable/undesirable students' behaviours } \\
\text { where appropriate } \\
\text { B2.2. } \begin{array}{l}\text { Keep records related to behavioural } \\
\text { management plan. }\end{array}\end{array}$ \\
\hline & $\begin{array}{l}\text { B3. Communicate with students with } \\
\text { SEN to assure their understanding } \\
\text { and maximum participation. }\end{array}$ & $\begin{array}{l}\text { B3.1. Use appropriate communication tools (e.g., } \\
\text { Braille, sign language, augmentative and other } \\
\text { alternative communication tools) }\end{array}$ \\
\hline \multirow[t]{2}{*}{$\begin{array}{l}\text { C. Evaluate learning progress of } \\
\text { students with SEN and } \\
\text { effectiveness of applied teaching } \\
\text { and support strategies. }\end{array}$} & $\begin{array}{l}\text { C1. Evaluate learning progress of } \\
\text { student with SEN in relation to } \\
\text { his/her Individual Education Plan } \\
\text { (IEP) goals. }\end{array}$ & $\begin{array}{l}\text { C1.1. Use appropriate evaluation tools to measure } \\
\text { students' progress in relation to the IEP } \\
\text { C1.2. Assign appropriate grade according to IEP. }\end{array}$ \\
\hline & $\begin{array}{l}\text { C.2. Evaluate the suitability of the } \\
\text { curriculum adaptations to students } \\
\text { with SEN } \\
\text { C.3. Evaluate effectiveness of } \\
\text { applied teaching and support } \\
\text { strategies. }\end{array}$ & $\begin{array}{l}\text { C2.1. Assess appropriateness of curriculum to } \\
\text { individual needs and abilities } \\
\text { C.3.1. Assess appropriateness of applied teaching } \\
\text { C.3.2. Assess appropriateness of support strategies }\end{array}$ \\
\hline
\end{tabular}




\begin{tabular}{|c|c|c|}
\hline \multirow[t]{4}{*}{$\begin{array}{l}\text { D. Professional collaboration to } \\
\text { improve teaching quality for } \\
\text { students with SEN }\end{array}$} & $\begin{array}{l}\text { D1 Collaborate with professionals in } \\
\text { APE. }\end{array}$ & $\begin{array}{l}\text { D1.1. Collaborate with other specialists providing } \\
\text { PE/APE. } \\
\text { D1.2. Collaborate with health and rehabilitation } \\
\text { professionals (e,g., Physiotherapist, } \\
\text { Occupational Therapist, Speech Therapist, } \\
\text { psychologists) } \\
\text { D1.3. Collaborate with the disability sport and } \\
\text { recreation representatives. }\end{array}$ \\
\hline & $\begin{array}{l}\text { D2 Collaborate with other advocates } \\
\text { of students with SEN }\end{array}$ & $\begin{array}{l}\text { D.2.1. Collaborate with parents/guardians of students } \\
\text { with SEN } \\
\text { D.2.2. Collaborate with Non- Governmental } \\
\text { Organisations (e.g., in children rights) }\end{array}$ \\
\hline & $\begin{array}{l}\text { D3 Improve professional skills and } \\
\text { knowledge }\end{array}$ & $\begin{array}{l}\text { D.3.1. Identify needs for professional development in } \\
\text { the area of APE. } \\
\text { D.3.2. Engage in continuing professional } \\
\text { development activities (e.g. reading } \\
\text { professional publications; attending } \\
\text { conferences (workshops, seminars) to learn } \\
\text { about new trends in APE). } \\
\text { D3.3. Communicate with other PE/APE specialists } \\
\text { to share your experiences and learn about the } \\
\text { examples of best practices. } \\
\text { D.3.4. Self-evaluate }\end{array}$ \\
\hline & $\begin{array}{l}\text { D4 Advocate for the needs and rights } \\
\text { of students with special educational } \\
\text { needs. }\end{array}$ & $\begin{array}{l}\text { D.4.1. Advocate appropriate support in physical } \\
\text { education service delivery for students with } \\
\text { SEN. } \\
\text { D.4.2. Advocate the utilisation of adapted physical } \\
\text { education specialist, teacher assistants or peers } \\
\text { tutors where appropriate. } \\
\text { D.4.3. Advocate for the rights of persons with SEN for } \\
\text { physical activities. }\end{array}$ \\
\hline
\end{tabular}

\section{Table 2 (continued)}

${ }^{\text {I }}$ Special educational needs (SEN), ${ }^{\text {II }}$ Adapted physical education (APE),

III Individual education plan (IEP), ${ }^{\text {IV }}$ Paraprofessionals

\section{Knowledge, Competence and Skills Framework in APE}

After completing the Functional Map more detailed analysis was carried out to develop the Knowledge, Competence and Skills Framework (KCSF), which describes Performance Requirements for APE teacher/consultant (Table 3). One of the most important things about the KCSF is that it is not intended to be a description of the competencies required by all individual APE practitioners. This document indicates the core knowledge requirements essential for all practitioners, but the competencies presented together with specific knowledge and skill requirements are an overview of key activities performed by one APE professional or by a team of people. It is important to note that the KCSF tries to reflect the best practice that will be required of APE professionals, not just today, but over the next few years. For this reason, it is an evolving framework and can

be updated to reflect the progress made in professional practice. The scope of the competences framework ranges from the preparation of the teaching environment through to application of teaching practice. The framework contains competencies that concern the broad population of APE teachers/consultants. The order of competence presentation does not indicate any chronological or functional order, or any order of importance, nor are any levels of competence indicated. Key competencies APE professionals should acquire can be divided in four areas focused on (1) preparation, (2) teaching, (3) evaluation and (4) collaboration and life-long learning. Competencies described in KCSF are (being able to perform): (a) assess the needs (current 
level of performance) of students with SEN; (b) adapt school curriculum in PE to meet the individual needs of all students with SEN; (c) plan developmentally appropriate learning experiences in APE; (d) prepare teaching environment before arrival of student with SEN; (e) adapt teaching in order to meet the needs of ALL students in PE; (f) manage students' behavior to assure the most appropriate and safe learning for ALL students in PE; (g) communicate with students with SEN to ensure their understanding and maximum participation; (h) evaluate learning progress of student with SEN in relation to his/her IEP goals; (i) evaluate the suitability of the curriculum adaptations to students with SEN; (j) evaluate the effectiveness of applied teaching strategies; (k) collaborate with various relevant professionals; (l) collaborate with other advocates of students with SEN; (m) improve professional skills and knowledge; and (n) advocate for the needs and rights of students with special educational needs. With all competencies we should consider range of students of school age with various SEN among which we can include (1) visual impairments, (2) hearing impairments, (3) learning disability, (4) moderate and light mental retardation, (5) language problems, (6) chronic diseases like diabetes, asthma, (7) physical problems, and (8) some psycho neurological diseases (Regulation Nr.542, LMES, 2003 from Latvia). Thus all APE professionals should acquire bellow specified knowledge also in relation to these SEN (and possible more in accordance with national regulations and legislation).

Table 3. Knowledge, Competence and Skills Framework in Adapted Physical Education

\begin{tabular}{|c|c|c|c|}
\hline $\begin{array}{l}\text { Performance } \\
\text { requirements }\end{array}$ & The range & $\begin{array}{l}\text { The skills the individual needs to } \\
\text { learn to do this }\end{array}$ & $\begin{array}{l}\text { The knowledge the individual } \\
\text { needs to learn to do this }\end{array}$ \\
\hline $\begin{array}{l}\text { Assess the needs } \\
\text { (current level of } \\
\text { performance) of } \\
\text { students with special } \\
\text { educational needs } \\
\text { (SEN) }\end{array}$ & $\begin{array}{l}\text { School age children } \\
\text { Special educational needs }{ }^{i}\end{array}$ & $\begin{array}{l}\text { - Select appropriate assessments } \\
\text { fitting the students profile } \\
\text { - Administer assessment } \\
\text { - Write the report }\end{array}$ & $\begin{array}{l}\text { - Special education needs } \\
\text { (different functional abilities, } \\
\text { motor, cognitive, social, } \\
\text { behavioral, communication) } \\
\text { - Variety of assessments } \\
\text { approaches (holistic, norm } \\
\text { reference, criterion based etc) } \\
\text { - Variety of assessments } \\
\text { (Movement ABC etc) } \\
\text { - Relevant regulations on report } \\
\text { writing and dissemination }\end{array}$ \\
\hline $\begin{array}{l}\text { Adapt school } \\
\text { curriculum in physical } \\
\text { education (PE) to meet } \\
\text { the individual needs of } \\
\text { all students with SEN }\end{array}$ & $\begin{array}{l}\text { School age children } \\
\text { Special educational needs }\end{array}$ & $\begin{array}{l}\text { - Analyze current PE curriculum } \\
\text { in relation to students needs } \\
\text { - Adapt curriculum }\end{array}$ & $\begin{array}{l}\text { - Current curriculum (school } \\
\text { district/national) } \\
\text { - Curriculum development } \\
\text { principles } \\
\text { - Curriculum adaptation } \\
\text { principles and strategies }\end{array}$ \\
\hline $\begin{array}{l}\text { Plan developmentally } \\
\text { appropriate learning } \\
\text { experiences in adapted } \\
\text { physical education } \\
\text { (APE) })^{\text {ii }}\end{array}$ & $\begin{array}{l}\text { School age children } \\
\text { Special educational needs }\end{array}$ & $\begin{array}{ll}\text { - } & \text { Ability to develop Individual } \\
\text { education plan (IEP) iii in PE } \\
\text { - } & \text { Ability to plan inclusive PE } \\
\text { lesson to ensure appropriate } \\
\text { and safe learning for all } \\
\text { students } \\
\text { Ability to plan appropriate } \\
\text { behavioral management } \\
\text { strategies } \\
\text { - Ability to plan motivation } \\
\text { strategies for students to } \\
\text { participate } \\
\text { Plan appropriate } \\
\text { communication strategies }\end{array}$ & 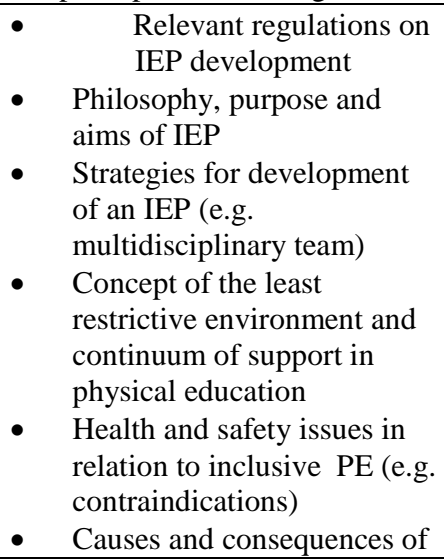 \\
\hline
\end{tabular}




\begin{tabular}{|c|c|c|c|}
\hline & & & $\begin{array}{ll} & \text { behavioral problems } \\
\text { - } & \text { Behavior management and } \\
\text { modification techniques } \\
\text { - } & \text { Motivation strategies } \\
\text { - } & \text { Communication strategies } \\
\text { (interpreter, communication } \\
\text { boards etc) }\end{array}$ \\
\hline $\begin{array}{l}\text { Prepare teaching } \\
\text { environment before } \\
\text { arrival of student with } \\
\text { SEN }\end{array}$ & $\begin{array}{l}\text { School age children, } \\
\text { assistant personnel. } \\
\text { Special educational needs }\end{array}$ & 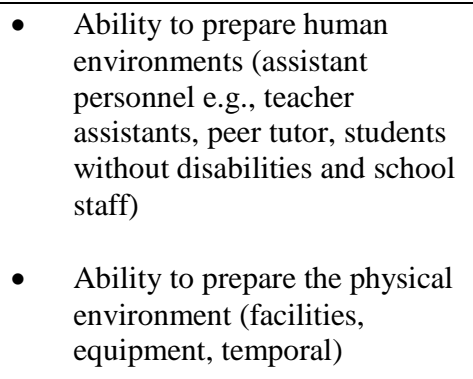 & $\begin{array}{ll}\text { - } & \text { Knowledge of peer } \\
\text { tutor/para-educator programs } \\
\text { - } & \text { School structures and } \\
\text { functions } \\
\text { - } \\
\text { Attitudinal theories and } \\
\text { disability awareness } \\
\text { - } \\
\text { Adaptation theory and } \\
\text { practical application in } \\
\text { relation to equipment etc. } \\
\text { - } & \text { Physical access issues }\end{array}$ \\
\hline $\begin{array}{l}\text { Adapt teaching in order } \\
\text { to meet the needs of } \\
\text { ALL students in PE }\end{array}$ & $\begin{array}{l}\text { School age children, } \\
\text { special educational needs }\end{array}$ & $\begin{array}{l}\text { - } \quad \text { Ability to use appropriate } \\
\text { instructional strategies (e.g., } \\
\text { physical/verbal cues, prompts, } \\
\text { feedback, reinforcement). } \\
\text { Ability to adapt the following: } \\
\text { - } \quad \text { the rules of games } \\
\text { - } \quad \text { physical setting } \\
\text { - } \quad \text { equipment } \\
\text { - Ability to use task analysis for } \\
\text { desirable skill } \\
\end{array}$ & $\begin{array}{l}\text { - Instructional strategies } \\
\text { - Adaptation strategies } \\
\text { - Adapted games, rules, } \\
\text { teaching styles } \\
\text { - Task analysis }\end{array}$ \\
\hline $\begin{array}{l}\text { Manage students' } \\
\text { behavior to assure the } \\
\text { most appropriate and } \\
\text { safe learning for ALL } \\
\text { students in PE. }\end{array}$ & $\begin{array}{l}\text { School age children. } \\
\text { Special educational needs }\end{array}$ & $\begin{array}{l}\text { - } \begin{array}{l}\text { Ability to provide } \\
\text { positive/negative reinforcement } \\
\text { of desirable/undesirable } \\
\text { students' behaviors where } \\
\text { appropriate }\end{array} \\
\text { - Ability to observe and keep } \\
\text { records related to behavioral } \\
\text { management plan. } \\
\text { - Ability to counsel/guide } \\
\text { students towards adopting } \\
\text { more appropriate behaviors - } \\
\text { choice }\end{array}$ & $\begin{array}{l}\text { - Identify and understand the } \\
\text { causes of behavioral problems } \\
\text { - Appropriate behavioral } \\
\text { management strategies and } \\
\text { theories (e.g., positive and } \\
\text { negative reinforcement, self - } \\
\text { actualization, self- } \\
\text { empowerment, Hellison } \\
\text { model etc.) }\end{array}$ \\
\hline $\begin{array}{l}\text { Communicate with } \\
\text { students with SEN to } \\
\text { ensure their } \\
\text { understanding and } \\
\text { maximum participation. }\end{array}$ & $\begin{array}{l}\text { School age children. } \\
\text { Special educational needs }\end{array}$ & $\begin{array}{l}\text { - Ability to use appropriate } \\
\text { alternative and augmentative } \\
\text { communication tools }\end{array}$ & $\begin{array}{l}\text { Appropriate communication } \\
\text { strategies for students with SEN } \\
\text { (e.g. Braille, sign language, } \\
\text { augmentative and other } \\
\text { communication tools) }\end{array}$ \\
\hline $\begin{array}{l}\text { Evaluate learning } \\
\text { progress of student with } \\
\text { SEN in relation to } \\
\text { his/her IEP goals. }\end{array}$ & $\begin{array}{l}\text { School age children. } \\
\text { Special educational needs }\end{array}$ & $\begin{array}{l}\text { - Ability to use appropriate } \\
\text { assessment methods to measure } \\
\text { students' progress } \\
\text { - Ability to grade the student } \\
\text { according to his/her potential and } \\
\text { progress. }\end{array}$ & $\begin{array}{l}\text { - Differing methods of } \\
\text { assessment } \\
\text { - Individualized holistic } \\
\text { approach for evaluating } \\
\text { student's progress }\end{array}$ \\
\hline $\begin{array}{l}\text { Evaluate the suitability } \\
\text { of the curriculum } \\
\text { adaptations to students } \\
\text { with SEN }\end{array}$ & $\begin{array}{l}\text { School age children. } \\
\text { Special educational needs }\end{array}$ & $\begin{array}{l}\text { - Ability to assess } \\
\text { appropriateness of curriculum } \\
\text { to individual needs and abilities }\end{array}$ & $\begin{array}{ll}- & \text { National PE standards } \\
\text { - } & \text { Curriculum adaptation } \\
& \text { strategies }\end{array}$ \\
\hline $\begin{array}{l}\text { Evaluate the } \\
\text { effectiveness of applied } \\
\text { teaching strategies }\end{array}$ & & $\begin{array}{l}\text { Ability to evaluate } \\
\text { effectiveness of applied } \\
\text { teaching and support strategies. }\end{array}$ & $\begin{array}{l}\text { - Methods and tools to assess } \\
\text { teaching and support } \\
\text { strategies (e.g., peer tutor } \\
\text { program, use of behavior } \\
\text { plan, adaptations to } \\
\text { environment, rules, task etc.) }\end{array}$ \\
\hline
\end{tabular}




\begin{tabular}{|c|c|c|c|}
\hline $\begin{array}{l}\text { Collaborate with } \\
\text { various relevant } \\
\text { professionals }\end{array}$ & $\begin{array}{l}\text { Paraprofessionals }{ }^{\text {iv }} \text {, APE } \\
\text { specialists, coaches, sport } \\
\text { instructors, administration of } \\
\text { sport organizations for } \\
\text { persons with disabilities. }\end{array}$ & $\begin{array}{l}\text { - Ability to collaborate with other } \\
\text { specialists providing PE/APE } \\
\text { - Ability to collaborate with health } \\
\text { and rehabilitation professionals } \\
\text { (e.g., physiotherapist, } \\
\text { occupational therapist, } \\
\text { speech therapist, psychologists) } \\
\text { - Ability to collaborate with sport } \\
\text { organizations, relevant } \\
\text { professional organizations for } \\
\text { persons with disabilities }\end{array}$ & $\begin{array}{l}\text { - The role of relevant } \\
\text { professionals and their } \\
\text { approaches in relation to APE } \\
\text { - Nature of cooperation } \\
\text { and communication with } \\
\text { support staff } \\
\text { - Team working } \\
\text { - Disability sport } \\
\text { organisations for potential } \\
\text { cooperation (e.g., local sports } \\
\text { clubs) }\end{array}$ \\
\hline $\begin{array}{l}\text { Collaborate with other } \\
\text { advocates of students } \\
\text { with SEN }\end{array}$ & $\begin{array}{l}\text { Parents/ guardians (legally } \\
\text { responsible), government } \\
\text { and non-governmental } \\
\text { organizations }\end{array}$ & $\begin{array}{l}\text { - Ability to collaborate with } \\
\text { parents/guardians of students } \\
\text { with SEN } \\
\text { - Ability to collaborate with Non- } \\
\text { Governmental and governmental } \\
\text { organizations (e.g., in children } \\
\text { rights) }\end{array}$ & $\begin{array}{ll}- & \text { Roles and rights of parents } \\
\text { guardians (legally } \\
\text { responsible) } \\
\text { - } \\
\text { Nature of cooperation and } \\
\text { communication with support } \\
\text { parents guardians (legally } \\
\text { responsible) } \\
\text { - } & \text { Team working } \\
\text { - } & \text { Rules and roles of relevant } \\
& \text { organizations } \\
\end{array}$ \\
\hline $\begin{array}{l}\text { Improve professional } \\
\text { skills and knowledge }\end{array}$ & APE/PE teachers & $\begin{array}{l}\text { - Ability to identify needs for } \\
\text { professional development in the } \\
\text { area of APE } \\
\text { - Ability to engage in continuing } \\
\text { professional development } \\
\text { activities (e.g. reading } \\
\text { professional publications; } \\
\text { attending conferences } \\
\text { (workshops, seminars) to learn } \\
\text { about new trends in APE } \\
\text { - Ability to share your experiences } \\
\text { with other APE teachers (e.g. } \\
\text { learn about the examples of best } \\
\text { practices) } \\
\text { - Ability to self-evaluate }\end{array}$ & $\begin{array}{l}\text { - Appropriate professional } \\
\text { development opportunities } \\
\text { - Sources of information (e.g. } \\
\text { in-service training, } \\
\text { associations, organizations } \\
\text { etc.) } \\
\text { - Tools for self evaluation in } \\
\text { relation to the ability to } \\
\text { implement PE/APE (e.g. } \\
\text { video recording and analysis } \\
\text { of sessions, written reports } \\
\text { etc.) }\end{array}$ \\
\hline $\begin{array}{l}\text { Advocate for the needs } \\
\text { and rights of students } \\
\text { with special educational } \\
\text { needs. }\end{array}$ & APE/PE teachers & $\begin{array}{l}\text { - Ability to advocate for equal } \\
\text { provision of PE for all students } \\
\text { - Ability to advocate for the } \\
\text { rights of students with SEN for } \\
\text { participation in PE/APE (e.g., } \\
\text { support services, adapted } \\
\text { equipment) }\end{array}$ & $\begin{array}{l}\text { - Legislation and relevant } \\
\text { national and international } \\
\text { policies } \\
\text { - Disability services, APA and } \\
\text { disability sports structures } \\
\text { - Educational structures and } \\
\text { services } \\
\text { - Advocacy approaches } \\
\text { (leverage, literature etc) }\end{array}$ \\
\hline
\end{tabular}

Table 3 (continued)

${ }^{\text {I }}$ Special educational needs (SEN), ${ }^{\text {II }}$ Adapted physical education (APE),
III Individual education plan (IEP), ${ }^{\text {IV }}$ Paraprofessionals

\section{SUMMARY}

European Commission recognizes and supports projects that promote its objectives for social policy towards non-discrimination for all its members. More specifically EC recognizes the necessity to move towards an inclusive education where students with and without SEN learn together into a general school system. The current situation in Europe however, requires substantial improvements towards the philosophy and the practice of inclusion of students with SEN into PE classes. The EUSAPA's project main objective was to bring together educational policies and strategies of social inclusion with the everyday school reality to 
inclusion/exclusion of students with SEN in PE. Some of the major conclusions are: (a) All PE teachers should receive an appropriate training in APE; (b) All professionals teaching PE in special schools or institutions for children and youth with disabilities should have an appropriate training in APE; (c) Appropriate support to PE of students with SEN should be provided by : (i) trained paraprofessionals (teacher assistants), (ii) peer tutors, (iii) using adapted equipment as necessary, and (iv) support of community sport services and, (d) adapted physical education consultants should be employed in all European countries in order to provide an appropriate support for physical education teachers in inclusive PE. These professionals could also work part time as PE teachers in special schools or classes and part time as APE consultants. The framework of competencies needed to become qualified APE professional is one of key outcomes of this project. Adapted physical education builds its APE related competencies on professional foundations in physical education and special education training programs. Finally, it is suggested that APE professionals should be prepared as a specialization within PE teacher education training with substantial space allocated for acquiring APE specific competencies developed as part of the EUSAPA project.

\section{REFERENCES}

Block, M.E, \& Obrusnikova, I. (2007). Inclusion in Physical Education: A Review of the Literature From 1995-2005. Adapted Physical Activity Quarterly , 24, 103-124.

Hardman, K. (2008). The situation of physical education in schools: A European perspective. Human Movement, 9(1), 5-18

Herold, F. \&Dandolo, J. (2009). Including visually impaired students in physical education lessons: a case study of teacher and pupil experiences. The British Journal of Visual Impairment, 27 (1), 75-84.
Jerlinder, K., \& Danermar, B. (2007). ANED country report on equality of educational and training opportunities for young disabled people: Sweden, Academic Network of European Disability experts (ANED) VT/2007/005

Kelly, L.K., \& Gansender, B. (1998). Preparation and job demographics of adapted physical educators in the United States. Adapted Physical Activity Quarterly, 15, 141-154.

Kudláček, M., Ješina, O., Štěrbová, D. \& Sherrill, C. (2008). The nature of work and roles of public school adapted physical educators in the United States. European Journal of Adapted Physical Activity, 1(2), 45-55.

Lienert, C., Sherrill, C., \& Myers, B. (2001). Physical Educator's Concerns About Integrating Children With Disabilities: A Cross-Cultural Comparison. Adapted Physical Activity Quarterly, 18, 1-17.

Lytle, R.K., Collier, D. (2002). The Consultation Process: Adapted Physical Education Specialists' Perceptions. Adapted Physical Activity Quarterly, 19, 261-279.

Lytle, R.K., \& Hutchinson, G.E. (2004). Adapted Physical Educators: The Multiple Roles of Consultants. Adapted Physical Activity Quarterly, 21, 34-49.

Morley, D., Bailey, R., Tan, J., \& Cooke, B. (2005). Inclusive Physical Education: teacher's views of including pupils with Special Educational Needs and/or disabilities in Physical Education. European Education Review, Vol II(I), 84-107.

O’Brien, D., Kudláček, M., \& Howe, P.D. (2009). A contemporary review of English language literature on inclusion of students with disabilities in physical education: A European perspective. European Journal of Adapted Physical Activity, 2(1), 46-61.

O‘Hanlon, C. (1993). Special Education Integration in Europe. David Fulton publishers. 
Sherrill, C. (2004). Adapted physical activity, recreation and sport: Crossdisciplinary and lifespan. $\quad\left(6^{\text {th }}\right.$ ed.). Boston, MA: WCB/McGraw-Hill. Special Educational Needs in Europe. Teaching Language to Learners with Special Needs. European
Commission, DG EAC 2303 LOT 3 2005.

Corresponding author's e-mail address: aija.klavina@gmail.com martin.kudlacek@upol.cz

\section{(Abstract) \\ BEWEGUNGSERZIEHUNG FÜR SCHÜLER/INNEN MIT BESONDEREN (LERN-) BEDÜRFNISSEN IN EUROPA: ERGEBNISSE DES EUSAPA PROJEKTS}

Adapted Physical Activity (APA) ist ein Berufsfeld für Dienstleistung und Vermittlung sowie ein Lehr- und Studiengebiet. Diese Studie beschreibt die Ergebnisse des Projekts 'European Standards in Adapted Physical Activity ' im Bereich von adapted physical education (APE -,,adaptierter Sportunterricht“). Die Unterschiede der Sondererziehung, einschließlich APE, in den 12 ProjektPartnerländern wurden identifiziert. Die akademischen Standards in APE wurden in vier Teilen definiert: (1) Professionelle Kompetenzen der Bewegungs-erzieher/innen; Tätigkeitsbeschreibung der Bewegungserzieher/innen; (3) Funktionsplan in APE; und (4) Bezugssystem Kenntnisse, Kompetenzen und Fähigkeiten in APE. Die Ergebnisse des Projekts werden mit den gefundenen weiteren Empfehlungen für die EU Kommission dargestellt, um die Implementierung von inklusiven Lehr- und Lernstrategien für Schüler/innen mit besonderen (Lern-) Bedürfnissen im Sportunterricht zu fördern.

SCHLÜSSELWÖRTER: adapted physical education / adaptierter Sportunterricht; Sondererziehung; besondere (Lern-)Bedürfnisse

\section{(Résumé) \\ L'EDUCATION PHYSIQUE EN EUROPE POUR DES ETUDIANTS EN SITUATION DE HANDICAP : RESULTATS DU PROJET EUSAPA}

L'activité physique adaptée (APA) est une profession de prestation de service et un domaine d'études académique. Cette étude rapporte les résultats du projet intitulé « Normes Européennes en Activité Physique Adaptée » (EUSAPA) dans le cadre de l'éducation physique adaptée. Les différences des services éducatifs spécialisés, incluant l'éducation physique adaptée (EPA), entre les 12 pays partenaires du projet ont été relevées. Les normes académiques de l'EPA ont été définis selon 4 points : 1) les compétences professionnelles des enseignants d'éducation physique, 2) une description occupationnelle des enseignants d'éducation physique, 3) une carte fonctionnelle de l'EPA, et 4) les connaissances, compétences et habiletés dans le domaine de l'EPA. De ce projet ont été émis des recommandations au sein de la Commission Européenne afin de promouvoir la mise en place de stratégies éducatives d'inclusion en éducation physique pour les élèves en situation de handicap.

MOTS CLES : éducation physique adaptée, besoins spécifiques éducatifs 


\section{(Аннотацця) \\ ФИЗИЧЕСКАЯ КУЛЬТУРА ДЛЯ СТУДЕНТОВ С ОСОБЫМИ ПОТРЕБНОСТЯМИ ОБРАЗОВАНИЯ В ЕВРОПЕ: РЕЗУЛЬТАТЫ ПРОЕКТА ЕСАФК}

Адаптивная физическая культура (АФК) является сферой предоставления услуг, а также научной областью исследования. Это исследование описывает результаты проекта "Европейские стандарты в адаптивной физической культуре" в области адаптивного физического образования. Были определены различия специальных образовательных услуг, в том числе адаптивная физической культуры в 12 странах-партнерах. Академические стандарты в АФК были определены в четырех частях: (1) профессиональная компетенция учителей физкультуры; (2) описание профессии, (3) Функциональная Карта в АФК; и (4) знаний, умения и навыки специалистов АФК. Результаты проекта с определенными дальнейшими рекомендациями для Комиссии ЕС были предоставлены в целях содействия реализации стратегии инклюзивного образования для учащихся с особыми образовательными потребностями в области физического воспитания.

КЛЮЧЕВЫЕ СЛОВА: адаптивная физическая культура; особые образовательные потребности

\section{(Resumen)}

\section{EDUCACION FISICA DE LOS ALUMNOS CON NECESIDADES EDUCATIVAS ESPECIALES EN EUROPA: RESULTADOS DEL PROYECTO EUSAPA}

Actividad Física Adaptada (APA) es una profesión de la prestación de servicios y un campo de estudio académico. Este estudio describe los resultados del proyecto Estándares Europeos en Actividad Física Adaptada en el área de educación física adaptada. Se identificaron las diferencias en los servicios de educación especial, incluida la Educación Física Adaptada (APE), en los 12 países socios del proyecto. El nivel académico de las APE se define en cuatro partes: (1) competencias profesionales de los profesores de educación física, (2) descripción de la ocupación de los profesores de educación física, (3) Mapa Funcional de APE, y (4) Marco de conocimientos, competencias y destrezas en APE. Los resultados del proyecto junto con identificación de nuevas recomendaciones para la Comisión Europea se proporcionan con el fin de promover la aplicación de estrategias de educación inclusiva para estudiantes con necesidades educativas especiales en educación física.

PALABRAS CLAVE: educación física adaptada, necesidades educativas especiales

\section{(Resumo) \\ EDUCAÇÃO FÍSICA PARA ALUNOS COM NECESSIDADES EDUCATIVAS ESPECIAIS NA EUROPA: RESULTADOS DO PROJETO EUSAPA}

A Atividade Física Adaptada (AFA) é uma profissão que envolve a prestação de serviços e um campo de estudo académico. Este estudo descreve os resultados do projeto das Normas Europeias de Atividade Física Adaptada na área de educação física adaptada. Foram identificadas as diferenças nos serviços de educação especial, incluindo a Educação Física Adaptada (EFA) nos 12 
países parceiros do projeto. Os padrões académicos em EFA foram definidos em quatro partes: (1) competências profissionais dos docentes de educação física, (2) descrição da carreira dos professores de educação física, (3) Mapa funcional da EFA, e (4) Conhecimento, Competência e Habilidades em EFA. Foram descritos os resultados do projeto e indicadas recomendações para a Comissão da UE, a fim de promover a implementação de estratégias de educação inclusiva para alunos com necessidades educacionais especiais na educação física.

PALAVRAS-CHAVE: educação física adaptada, necessidades educativas especiais 